\title{
The President's Role on National Security Policies - the Case of Kosovo
}

\author{
Behar Selimi ${ }^{1}$ \\ ${ }^{1}$ Faculty of Political Sciences, UBT Prishtina, Kosovo \\ Correspondence: Behar SELIMI, Faculty of Political Sciences, UBT Prishtina, Kosovo.
}

Received: February 23, 2017

Accepted: March 23, $2017 \quad$ Available online: March 27, 2017

doi:10.11114/ijsss.v5i4.2261

URL: https://doi.org/10.11114/ijsss.v5i4.2261

\begin{abstract}
The institution of the President in the Republic of Kosovo represents a new political and constitutional institution, as is the Republic itself. As such, he is still untested against constitutional responsibilities with which he is charged by the country's constitutions. Moreover, the President has not yet been tested on the security crisis management, as in reality he still cannot exercise all of his powers as Head of State and Commander in Chief of the Armed Forces, as these competencies for now are being exercised by the political and military structures of the North Atlantic Treaty (NATO). However, in a constitutional and legal sense, the President of Kosovo enjoys all the powers for the realization of his constitutional role as a "representative of the unity of the people and guarantor of the democratic functioning of the institutions of the country" and also as Commander of the Armed Forces with executive powers. Once the competences of the President in the authority of foreign policy are added then he appears to be one of the most powerful presidents, as compared with the presidents of parliamentary republics. It is exactly the powers of the President on national security issues that will be the topic of treatment in this paper, through an analysis not only the issues that are completely of the defense and security character, but also authorities dealing with other issues that can be used on behalf or in the name of national security.
\end{abstract}

Keywords: Kosova, president, national security, competencies

\section{Introduction}

Kosovo case is not typical for comparison as the institution of the head of state is a new institution and moreover still an untested system of governance. Kosovo continues even to this day lacking self-sufficiency in the field of national security, while in the field of law enforcement and public safety continues having international interaction and monitoring both in the police and prosecution office, as well as in the field of judiciary. Hence in matters of national security the main say lies with the bodies of the International Military Presence, which are a constitutional category (Kosovo Constitution. Article 153).

Kosovo has not yet developed sufficient political practice and constitutional basis on which a more complete analysis could be drawn. Especially a very poor practice appears to be evident regarding the full constitutional exercise of the head of state. However, existing constitutional and legal resources of various political acts represent a sufficient basis for a comparative formal and legal analysis, excluding terms of real political power.

Kosovar democracy is a purely international projection and based on the Arend Ljiphard's principles of consociational or power sharing theory (Ljiphard,1969) upon which the President Ahtisaari Comprehensive Plan has been drawn (Ramadani,2009)

This type of democracy is suggested for societies with deep ethnic, cultural, racial, ideological and other divisions, as a co-governance model that provides key social groups with a proportional sharing of power and mutual veto.

In the spirit of this theory the Constitution has also been designed, which took into account both the multi-ethnic co-governance and the potential co-governance of the leading political factors of the time. Hence the form of government in Kosovo is specific in comparison with similar forms of government and as such it is still under democratic testing. This form of government cannot be called a typical parliamentary republic, as the powers of the president and especially of the Prime Minister diminish the power of Parliament, therefore disallowing the Parliament to be the main body of legislative power. This relativization of legislative power is justified by Constitution, placing the Parliament on balance with executive and judicial power (Constitution, Article 4).

Based on these competencies and compared with comparative political theory, the Republic of Kosovo is an executive 
republic rather than a parliamentary republic. It could perhaps fall within Sartori's semi-parliamentary republic. It could even be called the prime ministerial republic similar to the German chancellor democracy. However, this form of government remains to be tested and shaped in the context of democratic development, which also can lead to a semi-presidential republic form of government characteristic of democracies in transition (Jashari \&Selimi, 2016)

\section{The President's Role}

The head of state is a new constitutional and political institution. Prior to 1990, Kosovo was a federal unit of the former Yugoslavia with autonomous status. Although it was an autonomous province it enjoyed representation (though not equally to republics) in all the federal power structures.

Governmental autonomous organization was a faithful imitation of both federal organization and power organization on the republican level (Bajrami, 2012). Consequently, apart from its legislative autonomous and constitutional power, which was exercised by three rooms representing municipalities, political social-communist organizations (all under the Communist League umbrella) as well as chambers representing "the working class" (United Labor House), Kosovo had also its executive autonomous power, which was exercised by the Presidency of the Province and the Provincial Executive Council (O.G No.4, February, 1974). Most of the powers exercised by presidents today, were once in rather formal legal terms practiced by presidencies, as collective chief of respective federal units and therefore collective head of the Autonomous Province. This situation continued until March 1989, when against the will of the people, and contrary to the federal Constitution Kosovo's autonomy was abolished.

The institution of the head of state or individual state chief was for the first time determined with amendments II-VI which amended the constitutional provisions of the Constitution of the Republic of Kosovo (September,1990) With these amendments the relevant articles are removed, regulating the organization and powers of the presidency and replacing them with provisions which determine the election procedure, functions and powers of the head of state, similarly to those now exercised by any president in a parliamentary republic (Bajrami,ibid.p.62).

However given that fact that Kosovo was under occupation the president had rather the role of a leader of the movement for independence than the one bearing real power as a president in a sovereign and independent state.

The struggle of the people of Kosovo by the KLA and the strong support of NATO's military, brought freedom along with the UN Resolution 1244, which placed Kosovo under the UN administration (Idem, p.75.)

""Resolution 1244 sanctioned in legal and political terms the situation of status quo, i.e. the situation that existed before the collapse of the constitutional position of Kosovo as defined by the Constitution of 1974". On the other hand by the resolution the entire state power was concentrated in the United Nations Mission in Kosovo (UNMIK), which means the power of the Head of State.

The Constitutional Framework of Kosovo was the first constitutional act of establishing a baseline legal order and thus formed the basis for the creation of institutions of self-government in Kosovo after the war. Within the framework of government institutions, the framework recognizes the institution of the President, although with very limited powers in general, and those of security in particular. In fact, the Constitutional Framework does not recognize the President as an authorization or power on security issues, whether public or national. (UNMIK Regulation, No.2001/9)

According to the Constitutional Framework all powers in security matters have been reserved for the head of the international mission (UNMIK) and the military mission (KFOR), NATO.

Later with the Comprehensive Proposal for the Kosovo Status Settlement (Ahtisaari Plan) the President's position was somewhat consolidated with usual powers of a head of state in a parliamentary system, however this act too did not predetermine the president's powers in security matters (Idem, Chapter VIII ).Although a part of the security sector, especially the public one, had been entrusted to local institutions, national security was entirely in the hands of the international community. Even the powers that were entrusted to Kosovo institutions had to be exercised according to the instructions and under the supervision of the International Civilian Representative and the International Military Presence.

Finally the adoption of the Constitution of Kosovo (April 9, 2008) brought substantial changes in the definition of the new legal order in Kosovo and also vindicated its legally declared independence on February 17, 2008.

The new constitution (still in force) not only recognized the institution of the President, but it granted relatively large powers to him/her, especially in the field of national security and foreign policy leadership. Speaking again in formal legal terms, it should be reiterated that the final authority in the field of national security continues to remain with NATO through KFOR.

Under the Constitution the President of Kosovo is one of the most powerful presidents in comparison with the presidents of parliamentary republic in which the President is elected by the Parliament (Bajrami,2012:278). He may be even 
stronger in relation with some presidents of parliamentary republics, who shall be elected directly by the people.Example: The President of Kosovo has more competences than that of Macedonia, Serbia, Slovenia, etc., especially on foreign affairs dhe matters of security.

\section{What are the Powers of the President?}

The constitutional and political power of the Head of State of the Republic of Kosovo is determined mainly by the Constitution. So the Constitution has gone about in detail and does not leave much space for need for legislation, which would more closely regulate his/her position. In fact there is a law on the President (Law No. 03/L-094.), which regulates the procedure and criteria for his/her appointment and discharge, including the organization of his/her office and his/her privileges rather than competences. For the competencies there is only one article, relating to the powers of the President referring to powers as defined by the Constitution.

If one looks at the Constitution of Kosovo, it will be clearly noticeable both the definition of responsibilities as well as their large number. In political and academic communication only 30 competencies are usually mentioned, as defined in Article 84 of the Constitution of Kosovo, which regulates the powers of the President exclusively. Yet the President has other powers, which are set with other articles of the Constitution, which regulate other issues of power and state regulation.

According to Prof. Bajrami, one of the most famous Albanian constitutionalists and one of the authors of the Constitution of Kosovo, the powers of the President of Kosovo can be divided into executive, interdependent and ceremonial (Bajrami,op.cit. p.275)

For the purposes of our paper we will only mention here the authority dealing with security issues, whether directly or indirectly.

\section{Executive Competences}

Most of the competencies in the field of security fall within the executive and interdependent framework. Within the executive powers of this kind we believe that the following competencies are included:

1) Representation of the Republic of Kosovo, internally and externally;

2) Ensuring the constitutional functioning of the institutions of state power;

3) The conduct of foreign policy;

4) Issuing of decrees;

5) The right of suspension veto to the laws passed by the Assembly;

6) The right to propose laws and constitutional amendments;

7) The right to challenge the constitutionality of laws and other issues raised at the Constitutional Court;

8) The signing of international agreements;

9) $\mathrm{He} / \mathrm{she}$ is the Supreme Commander of the Kosovo Security Forces and,

10) Leads the Consultative Council for Communities (Kosovo Constitution, Article 4).

Powers under the numbers 1, 2, 3, 4, 5 and 8 can also be exercised for security policy issues. For example, representation and management of foreign affairs in the majority of cases are related to security issues. Foreign affairs conceptually and actually cannot be separated from national security policies, knowing that at any ratio or relationship in which a state enters with a state or other states should consider first and foremost the national security interests before any of other character.

And the right of the President to draft laws from his/her scope of activity (Ibid, Article 79), can also be used to draft laws that regulate matters of the law for the security forces, the Law on Intelegence Agency (KIA), etc., that regulate matters that fall within the scope of the President as head of state and Supreme Commander of Kosovos Secusrity Force (KSF). In addition, the right to propose constitutional amendments can be used to change the articles of the constitution, which regulate the security sector and the mechanisms of creation and implementation of national security policies

The power to return laws for reviewing and of sending them to the Constitutional Court is also a good opportunity for the President to influence the entire security sector. As an example, one needs to mention the case of return of the law on Kosovo police in 2012 (President's Decision 111/1). This is a typical example of the use of suspension veto in the name of national security policy and constitutional functioning of the institutions. The President Jahjaga (in office during 2011-2016), considered that the Law on Police as it was approved in the Assembly was not in accordance with the National Strategy for Integrated Border and that the regulation of organization and functioning of senior police management, among others "would invalidate the progress made by minorities in the Kosovo Police" (Idem.p.4). So she 
considered that the law was detrimental to the legitimate interests of the country and detrimental to the interests of minorities. The return of the law for re-examination brought about changes in the law on the controversial parts by the President together with the changes required to be adopted by the Assembly.

Within the powers listed above is the power of the President to lead the Consultative Council for Communities (Constit. Article 60). Although the Council has no competence to deal with issues of security, social stability and economic, cultural and political minorities it is a precondition for stability and national security. Therefore the discussion of topics that concern the community members and offer solutions are a good opportunity for the President to contribute to civic unity and national stability. One of the powers of the Council is "the possibility of communities for comment at an early stage of legislative and policy initiatives, which can be prepared by the government, so that by suggesting initiatives such communities can seek to have their views included in relevant projects and programs" (Idem,Article 60.2).

So this Council can play an important role in creating security policies of communities when dealing with laws or policy documents, which in one way or another are dealing with security issues.

\section{Interdependent Competencies}

Within the framework of interdependent competences the President is the authority of the majority of appointments in both the justice sector and security sector. The President cannot exercise these powers independently but rather in cooperation and collaboration with the Government and Parliament. A part of the appointments by the President are made in cooperation with the Parliament as e.g. the appointment of the Auditor General, whom he proposes and the Assembly adopts; or the proposal of the Constitutional Court judges, who are elected by Parliament, but appointed by the President, etc.

The rest of interdependent powers in the area of appointments the President exercises in conjunction with the administration of the justice system (Prosecutorial Council and Judicial Council). And the president has final authority of appointment of the State Prosecutor and all prosecutors upon Prosecutorial Council's proposal, including the President of the Supreme Court and all judges on the proposal by the Judicial Council.

Within these competences in the field of security can be mentioned the top appointments to key national security institutions, which are made in close cooperation and interaction between the President and Government. One should also mention the competences in exceptional situations, which cannot be exercised independently either by the Government or President. Some of the most important powers of this nature are the following:

- The appointment of the KSF Commander after recommendation by the Prime Minister;

- Together with the Prime Minister, the President appoints the Director, Deputy Director and Inspector General of Kosovo Intelligence Agency;

- He declares a state of emergency in consultation with the Prime Minister;

- The right to receive the same intelligence information as the Prime Minister;

- The President promotes the ranks of General upon a joint proposal by the KSF Commander and the Minister according to the Law on KSF;

$-\mathrm{He} / \mathrm{she}$ has the authority to demand Security Council meetings of Kosovo and under exceptional circumstances to chair them, etc.

Kosovo Security Council is an atypical case of National Security Councils for both the fact that it is subordinated to the President and because it has an expanded composition of members representing both the executive and legislature. Although he/she is neither a leader nor a member Council, the President is represented by one of his advisers. The impact of the President in the Council's meetings is small, as his representative, although a permanent member, has no voting rights and his role is rather advisory and of the same level as that of the executives operating in the security sector (Law on establishing Kosovo Security Council, No. 03/L-050, Article 3). Yet the President is the constitutional authority to ask for meetings of the Security Council and the Council is obliged to coordinate its work closely with the President. Of particular importance is the constitutional obligation of the Security Council to prepare its Security Strategy in cooperation with the President, as well its legal obligation to provide advice whenever the President demands it.

So browsing on the basis of the constitutional order either on the capacity of participation, or his/her constitutional and legal powers, the President of the Republic of Kosovo in times of peace neither chairs the Council nor has any substantial impact neither formally nor legally, nor political influence on the organization and functioning of the Council. The situation is completely different when a state of emergency is declared, both when emergency measures are needed to protection and prevention and combating of internal threat to the constitutional order or public security and when facing natural disasters in the entire country or in one part of it (Ibid, Article 2, Paragraph 2.9). 
During a state of emergency the Kosovo Security Council passes under the responsibility of the President and he exercises executive powers in a similar composition of the normal state time.

The Kosovo Security Council, in both circumstances of peace and a state of emergency has the following composition: Prime Minister, ministers of foreign affairs, defense, interior, justice, finance and Minister for Returns and Communities. These are permanent members with executive status. Also permanent members of the Council, without an executive status are also advisors to the President, Advisor to the Prime Minister, the Director of KIA, General Director of KP, Director of Customs, Director of the Department of Emergency Management and Secretary Council. Chairman of the Parliamentary Committee for Community Safety can also take part in the meeting with an observer status (Law No. 03/L-050).

From the analysis of the relation of the President with of the Security Council in circumstances of peace, one may conclude that he has a weak position as compared with leaders in the parliamentary republics in which the President chairs over the Council in peacetime circumstances as well.

Regarding the state of emergency the Kosovo Constitution has provided and arranged two possible situations in which the President is the main authority for declaring and decreeing measures to be taken (Constitution, Articles 131).

The first situation has to do with the circumstances of the "state of defense", which can occur in case of violation of territorial integrity, independence and sovereignty of the country. In such circumstances, "the President after consultation with the Prime Minister declares a state of emergency. In these circumstances, "the President after consultation with the Prime Minister declares a state of emergency. With the declaration of the State of Emergency, the President of the Republic of Kosovo shall immediately issue a decree setting forth the nature of the threat and any limitations on rights and freedoms. Within forty-eight (48) hours, the Assembly may provide its consent by two thirds $(2 / 3)$ vote of the members present and voting. If consent is not provided, the President's decree has no force or effect" (Ibid, Article 131.3).

In case of a threat for the constitutional order and public safety, or a natural disaster in the territory of Kosovo or in a part of the territory, the President again in consultation with the Prime Minister declares a state of emergency and by decree defines the nature of the threat as well as measures to be taken to deal with security threats and risks. In these cases too within the Assembly must give its consent within 48 hours, but now for the confirmation of the President's decree a qualified majority is not required, and votes of the majority of members present and voting suffice.

The Constitution does not foresee a situation when the Assembly, due to the emergency situation is objectively prevented to meet and therefore it has not determined the power of the President to continue the situation even when consent is not provided within the constitutional deadline. This gap must be filled because the state of emergency is one of the political and constitutional institutions that can turn into opportunities for autocratic and totalitarian regimes.

Principally a state of emergency cannot last more than 60 days, and except in cases when it is necessary, the Assembly may authorize the continuation of the state for 30 days and it only takes a simple majority. And if the President determines that the threat is extraordinary, the Assembly may authorize appropriate measures for longer than 150 days, though this authorization requires a qualified majority of $2 / 3$ of all deputies.

The Constitution authorizes the President in exceptional circumstances, after consultation with the Prime Minister, to order mobilization of the KSF to help during emergency situations. This can be interpreted as a commitment of the army in support of the police and emergency services in case of need, because in the circumstances of the "state of defense", i.e. attack on the country, the President is the Supreme Commander and concurrently Head of the Security Council, therefore, he/she represents the leading authority on defense and security.

\section{Conclusions}

Based on an analysis of constitutional and legal position of the President of the Republic of Kosovo in relation to other organs of state power, one may conclude that he/she has all the powers necessary to fulfill his/her mission in the capacity of the head of state and army general commander. Of course, these powers could be exercised in full following the completion of the NATO mission in Kosovo, when the process of building the state and with it sovereignty is expected to be completed.

The President, as the leader of foreign policy, however, is one of the main factors in national security policy, given the fact that national security is inseparable with the country's foreign policy.

The national security strategy cannot be developed or approved without the consent of the President, and the Security Council, although under the authority of the Prime Minister, serves as an advisory body to the President, whenever the latter requests it. In war circumstances, however, the Council's executive body is subordinated directly to the President.

Moreover, the Director of the Intelligence Agency (KIA), is obliged to inform the President about the state of national 
security, in the way it informs the Prime Minister. in the meanwhile KSF is directly subordinated to the command of the country's president.

Besides direct competences in the field of defense and security, the President of Kosovo has an additional range of powers through which he/she may exercise an impact on the security and defense policies. The most important ones are the powers in legislation, such as the right to suspensive veto, the right to propose laws in the scope of his/her activity; proposal for amendments to the constitution; the right to dispute laws at the Constitutional Court, etc. All these powers can be used for matters directly related to defense and security issues and therefore make Kosovo President be worn enough power to meet the requirements for protecting the integrity, independence and sovereignty country and to guarantee the constitutional functioning of the institutions of the country.

\section{References}

Bjrami, A. (2012). Sistemi Kushtetues i Republikës së Kosovës, (Constitutional System of Republice of Kosovo) Printing House "ARTINI", Prishtina,

Comprehensive Proposal for the Kosovo Status Settlement (CSP),Plani Gjithëpërfshirës për Zgjidhjen e Statusit të Kosovës.

Constitutio, Revistë studimore për çështje juridike-kushtetuese dhe parlamentare, (Journal for Constitutional and Parliamentary Issues) $1 / 2012$, Prishtina

Juan, J. L., \& Arturo, V. (1994). The Failure of Presidential Democracy, Comparative Perspectives. The Johns Hopkins University Press, Baltimore and London,

Kushtetuta, K. (1974). (Constitution of Former Province of Kosovo), Gazeta Zyrtare e KSAK, nr.4 (27 February).

Kushtetuta, K. (2009). Constitution of Kosovo, April.

Law On Kosovo Intelegence Agency,Law No. No. 03/L-063, Ligji për Agjencinë e Kosovës për Intelegjencë.

Law on Kosovo Security Force, Law No. 03/L-046 ,Ligji për FSK-në.

Law On the Establishment of the Kosovo Security Concil, Law No. 03/L-050, Ligji për themelimin e Këshillit të Sigurisë së Kosovës.

Lijphart, A. (1969). Cosociational Democracy. World Poltics, 21(2), 207-225. https://doi.org/10.2307/2009820

Murat, J., \& Behar, S. (2016). Kosovo An Atypical Parliamentary Republic. Academicus International Scientific Journal. https://doi.org/10.7336/academicus.2016.14.07

President's Decision Nr.111/1,09.02.2012.

Ramadani,Burim.(2009).State of communities-in implementation of the Ahtisaari Plan. "Shteti i Komuniteteve - Në zbatim të Planit të Ahtisarit", Prishtina.

UNMIK Regulation, Nr.2001/9.

\section{Copyrights}

Copyright for this article is retained by the author(s), with first publication rights granted to the journal.

This is an open-access article distributed under the terms and conditions of the Creative Commons Attribution license which permits unrestricted use, distribution, and reproduction in any medium, provided the original work is properly cited. 